\title{
Infection due to exposed aortic prosthetic graft in perforated duodenal ulcer
}

\author{
Hideki Ito, Hiroko Yano, Takayuki Ishii, Tsutomu Sawada
}

General Medicine, Kochi Health Sciences Center, Kochi, Japan

\section{Correspondence to}

Dr Hideki Ito;

hidekito2@ab.auone-net.jp

Accepted 21 September 2020

\section{DESCRIPTION}

An 82-year-old woman presented to our hospital with fever and fatigue. She underwent artificial blood vessel replacement for abdominal aortic aneurysm 11 years ago and had been in good health until 3 years ago. For one of symptoms or illnesses such as polyarthralgia, vertebral osteomyelitis (VO), sepsis, fever and hyponatraemia, she had been admitted to our hospital six times for 3 years until the current hospitalisation. She underwent posterior lumbar fusion for VO 3 years ago. Whenever she was admitted to our hospital, laboratory tests revealed leucocytosis and elevated levels of $\mathrm{C}$ reactive protein (CRP), suggestive of bacterial infection. She always needed appropriate antimicrobial therapy. Imaging tests had failed to identify the source of infection, except for VO.

On this seventh admission to our hospital, the patient complained of fever only. Initially, urinary tract infection was suspected with leucocyte count of $15.9 \times 10^{9} / \mathrm{L}$, elevated CRP of $9.3 \mathrm{mg} /$ $\mathrm{dL}$ and urinary sediment leucocyte of 30-49 cells per high-power field. Blood culture and urine culture both yielded Klebsiella pneumoniae. No abnormal accumulation was found in a scintigram of gallium-67 citrate. Enterococcus faecium grown in blood culture of the sixth admission and $K$. pneumoniae were both bacteria commonly detected in the intestinal tract. Bacteraemia could be accounted for by transmission of bacteria from the intestinal tract. A CT scan of the abdomen with intravenous contrast showed small, previously unrecognised ectopic air in the space between the abdominal aortic graft and the overlying third duodenal portion, but no features of perigraft infection (figure 1). There was no extravasation of aortic contrast material from the graft. We suspected fistula formation between the abdominal aortic graft and the posterior wall of the third duodenal portion, and performed an upper gastrointestinal endoscopy. Perforated ulcer

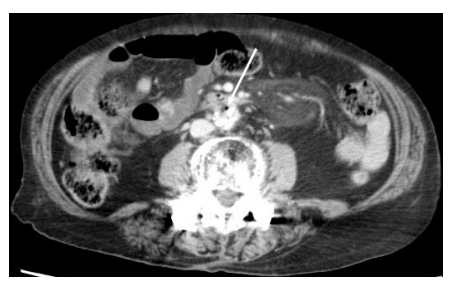

Figure 1 Axial view of contrast-enhanced CT showing the presence of ectopic air (arrow) in the space between the abdominal aortic graft and the third duodenal portion.

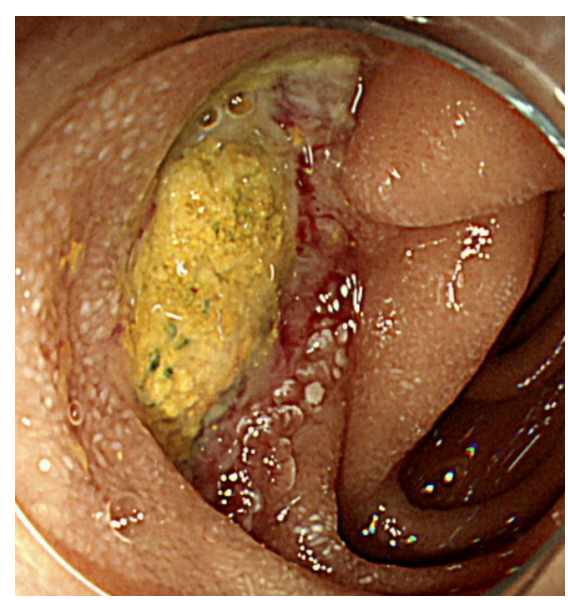

Figure 2 Upper gastrointestinal endoscopy showing a yellow exposed graft with green dot marks on the surface.

with no sign of active bleeding was found in the third duodenal portion. At the site of the ulcer, a yellow exposed graft with green dot marks on the surface was observed (figure 2). We confirmed the diagnosis of secondary aortoduodenal fistula (SADF). In this regard, graft infection by enteric bacteria in the third duodenal portion may have been the cause of a series of bacterial infections. Axillobifemoral bypass, duodenal ulcer closure

\section{Patient's perspective}

I was hospitalised many times for infectious diseases and had a hard time. After being explained about the cause of infection, I took the plunge and underwent surgery. I was sick for a while after surgery, but I'm glad I finally got well and did not get a fever.

\section{Learning points}

- This patient presenting with recurrent bacteraemia after abdominal aortic surgery emphasises the importance of suspecting aortic graft infection attributable to secondary aortoduodenal fistula (SADF).

- The diagnosis of SADF is not easy and often delayed because of the diagnostic difficulty.

- A careful examination of the third duodenal portion with an upper gastrointestinal endoscopy may help diagnose SADF. 
and abdominal aortic stump closure were performed without aortic graft excision. No fever was observed for 9 months after the bowel and vascular reconstruction.

One of possible causes of SADF includes pulsatile mechanical forces into the duodenum. ${ }^{1}$ According to a study of 37 secondary aortoenteric fistula (SAEF) cases, the incidence of aortic graft infection (AGI) was reported at $2 \%$ among the 4137 patients operated. SAEF is one of possible causes of AGI and was identified in $45 \%$ of AGI. $^{2}$ SAEF can occur in any part of the gastrointestinal tract, with the third duodenum portion being two-thirds. ${ }^{3}$ For many, SADF causes massive, life-threatening bleeding. ${ }^{34} \mathrm{CT}$ should be the first modality in patients of suspected AGI or SAEF. ${ }^{5}$ In case of being inconclusive, an upper gastrointestinal endoscopy should be performed as in this patient.

Contributors $\mathrm{HI}$ completed and wrote the article. HI, HY, TI and TS were involved in the clinical management of the patient.
Funding The authors have not declared a specific grant for this research from any funding agency in the public, commercial or not-for-profit sectors.

Competing interests None declared.

Patient consent for publication Next of kin consent obtained.

Provenance and peer review Not commissioned; externally peer reviewed.

\section{REFERENCES}

1 Armstrong PA, Back MR, Wilson JS, et al. Improved outcomes in the recent management of secondary aortoenteric fistula. J Vasc Surg 2005;42:660-6.

2 Batt $\mathrm{M}$, Jean-Baptiste $\mathrm{E}, \mathrm{O}^{\prime} \mathrm{C}$ onnor $\mathrm{S}$, et al. Early and late results of contemporary management of 37 secondary aortoenteric fistulae. Eur J Vasc Endovasc Surg 2011:41:748-57.

3 Simó Alari F, Molina González E, Gutierrez I, et al. Secondary aortoduodenal fistula and the unrecognised herald bleed. BMJ Case Rep 2017;2017. doi:10.1136/bcr-2017220186. [Epub ahead of print: 20 Oct 2017].

4 Miyamoto K, Inaba M, Kojima T, et al. Intra-Aortic balloon occlusion (IABO) may be useful for the management of secondary aortoduodenal fistula (SADF): a case report. Int J Surg Case Rep 2016;25:234-7.

5 Orton DF, LeVeen RF, Saigh JA, et al. Aortic prosthetic graft infections: radiologic manifestations and implications for management. Radiographics 2000;20:977-93.

Copyright 2020 BMJ Publishing Group. All rights reserved. For permission to reuse any of this content visit

https://www.bmj.com/company/products-services/rights-and-licensing/permissions/

BMJ Case Report Fellows may re-use this article for personal use and teaching without any further permission.

Become a Fellow of BMJ Case Reports today and you can:

- Submit as many cases as you like

- Enjoy fast sympathetic peer review and rapid publication of accepted articles

- Access all the published articles

Re-use any of the published material for personal use and teaching without further permission

Customer Service

If you have any further queries about your subscription, please contact our customer services team on +44 (0) 2071111105 or via email at support@bmj.com.

Visit casereports.bmj.com for more articles like this and to become a Fellow 